Marion Struck-Garbe

\title{
8 Reflections on Climate Change by Contemporary Artists in Papua New Guinea ${ }^{85}$
}

\subsection{Introduction}

This chapter extends the discussion of scientific, policy and cultural discourse on climate change to an artistic perspective on the issue. It aims to draw attention to a Pacific culture as seen through the eyes of its contemporary artists, and explores the knowing, multiple and often ironic ways in which artists are responding to reductive images and subverting stereotypical assumptions. Artistic responses here combine representational and revelatory knowledge-practices, and the chapter is therefore also a creative experiment in depicting these contested tensions, and similarly moves between modes of knowledge in being faithful to "outsider" views of how climate change in Papua New Guinea might be seen, and being faithful to these "insider" artistic responses. One effect of this experiment is that the narrative may at points sit uncomfortably with depictions of similar themes and similar venues elsewhere in this volume. In destabilising these positions in knowledge, the chapter voices the assertions, tensions and predicaments through which climate change knowledge is being made, revealed and understood.

The consequences of climate change are already felt in Papua New Guinea, especially on the atoll islands. Between 3,500 and 6,000 dwellers will need to resettle due to increasing land loss, salt-water inundation and growing food insecurity. Once resettled as "climate refugees" at nearby Bougainville Island, they are losing their selfsufficiency as well as their cultural identity. Papua New Guinean artists are conscious of local issues and through their contribution they are documenting major social and environmental concerns of their people, trying to highlight how they think and feel about the threat of climate change.

Contemporary art has been a focus of local artists since the 1970s. Usually, themes and motives are dealing with changes in society, depicting scenes of traditional and cultural events or body art and decorated dancers. More recently, some artists started to focus explicitly on environmental issues. Losing one's home and culture due to the consequences of climate change, losing the forest due to logging by multinational

85 An earlier version of this chapter appeared in Pacific News, 38, July/August 2012.

Marion Struck-Garbe, University of Hamburg 
companies or staying hungry because of fish shortage due to over-fishing have become their concern. Papua New Guinean artists' art can challenge the perception of and the relationship with climate change and environmental modifications by deconstructing common views and revealing alternative perceptions. By presenting and commenting on their motives (see artist biographies in footnotes, and Struck-Garbe, 1998), I want to show and creatively convey how this fear of loss is reflected in their artwork.

\subsection{Climate Change in Papua New Guinea}

Papua New Guinea is highly exposed to the effects of climate change and has often experienced extreme weather conditions. Some of the 600 islands of this Pacific Island state experience flooding and severe cyclones more often than in previous years. Manus, Duke of York, Siassi Islands, Mortlock, Tasman and Nurguira Island and Carteret Islands have recorded rising sea levels in the last two decades and it must be feared that in the long-run, rising sea levels will lead to significant land losses. Coastal flooding is already a serious problem affecting thousands of people every year and causing migration to less affected areas. Coral reefs are suffering from bleaching due to rising ocean temperatures and further falling under threat from ocean acidification.

Average rainfall is projected to increase in most areas especially during La Niña events. ${ }^{86}$ This will cause flooding and landslides with adverse effects on peoples' lives in the coastal and low land areas, as well as in the highlands. Rising flood waters at the coastlines and in the river areas are also attributed to consequences of climate change. For instance, during spring 2010 many communities along the Sepik River experienced the worst flood in 40 years. An estimated twenty thousand people of the East Sepik Province were affected. But residents have been able to sustain themselves. There are inter-community supply chains thanks to traditional coping mechanisms, so that people had enough food and shelter.

The El Niño phenomenon has led to droughts which are associated with bush fires, fresh water problems and even frost. In the wake of this event serious health problems and food shortage evolved because sweet potato and other crops withered. As happened in 1997-8, Papua New Guinea then relied on foreign aid to support her people.

Another climate change issue is deforestation, which is rarely mentioned in conjunction with the Pacific Islands. The forest's importance for carbon storage has

\footnotetext{
86 La Niña is characterized by unusually cold ocean temperatures in the Equatorial Pacific, compared to El Niño, which is characterized by unusually warm ocean temperatures. El Niño and La Niña result from interaction between the surface of the ocean and the atmosphere in the tropical Pacific. Changes in the ocean impact the atmosphere and climate patterns around the globe. In turn, changes in the atmosphere impact the ocean temperatures and currents. The system oscillates every 3 to 4 years between warm (El Niño) to neutral or cold (La Niña) conditions. http: //www.elnino.noaa.gov/ lanina_new_faq.html.
} 
been realised fairly recently. Rainforests play a key role in regulating local and global climates. Their massive degradation and destruction result in a loss of natural carbon storing and leads to an increase of greenhouse gas emissions.

Papua New Guinea is still hosting some of the world's largest and remaining intact forest landscapes. The forests have always provided a livelihood but due to continued legal and illegal destructive logging and the conversion of forest areas into plantations, the forests and living environment of the people are now under threat.

The observed impacts of climate change pose threats to the $85 \%$ of the population who make their living from gardening, agriculture, fisheries and the forests. It is furthermore an immediate threat to the development aspirations of the country which now has to tackle adaptation and to address mitigation plans and to deal with damages due to the impacts of climate change.

\subsection{Sinking Islands}

It was widely reported in November 2005 that the low-lying Carteret Islands of Papua New Guinea have progressively become uninhabitable, with an estimate of their total submersion by $2015 .{ }^{87}$ The islands gained some dubious fame, because the inhabitants are being called one of the world's first climate refugees.

The islanders have fought a more than twenty years' battle building a seawall and planting mangroves. However, storm surges and high tides continue to wash away homes, destroy vegetable gardens and contaminate fresh water supplies. Due to the loss of land and due to inundation, the islanders are no longer able to grow crops, such as bananas and taro, to feed themselves. Families survive on mainly fish and coconuts, and are battling the swamp mosquitoes that have brought malaria.

The smallest tiny islands in their atoll and a considerable part of the total land mass of the Carteret atoll have disappeared already and in foreseeable years the rest of the land mass of the atoll is likely to submerge. Due to the fact that the area is small in size and lowlying, inhabitants will have nowhere to retreat to as the seas inundate their coastlines.

Carteret Islanders now have to move permanently to another place, to find a new home. In July 2009, nearly 3,000 islanders began what will eventually become a fullscale evacuation to Bougainville, the next major island about 80 kilometres away from their ancestral grounds. Relocation will continue over the next ten to twenty years. As the national and local government's relocation plans are slow the islanders have set up a relocation team. In 2006, they founded the local NGO Tulele Peisa. The

87 Pacific Small Islands Developing States, United Nations Members, 2009, Views on Possible Security Implications of Climate Change to be included in the report of the Secretary-General to $64^{\text {th }}$ Session of the United Nations General Assembly, p. 11; http: //www.un.org/esa/dsd/resources/res_pdfs/ ga-64/cc-inputs/PSIDS_CCIS.pdf 
name can be translated as "sailing the waves on our own." Their aim and task is to support and facilitate the voluntary resettlement of the islanders. They campaign for social justice on behalf of the Carteret Islanders and raise money to implement their own relocation program (Struck-Garbe, 2009a).

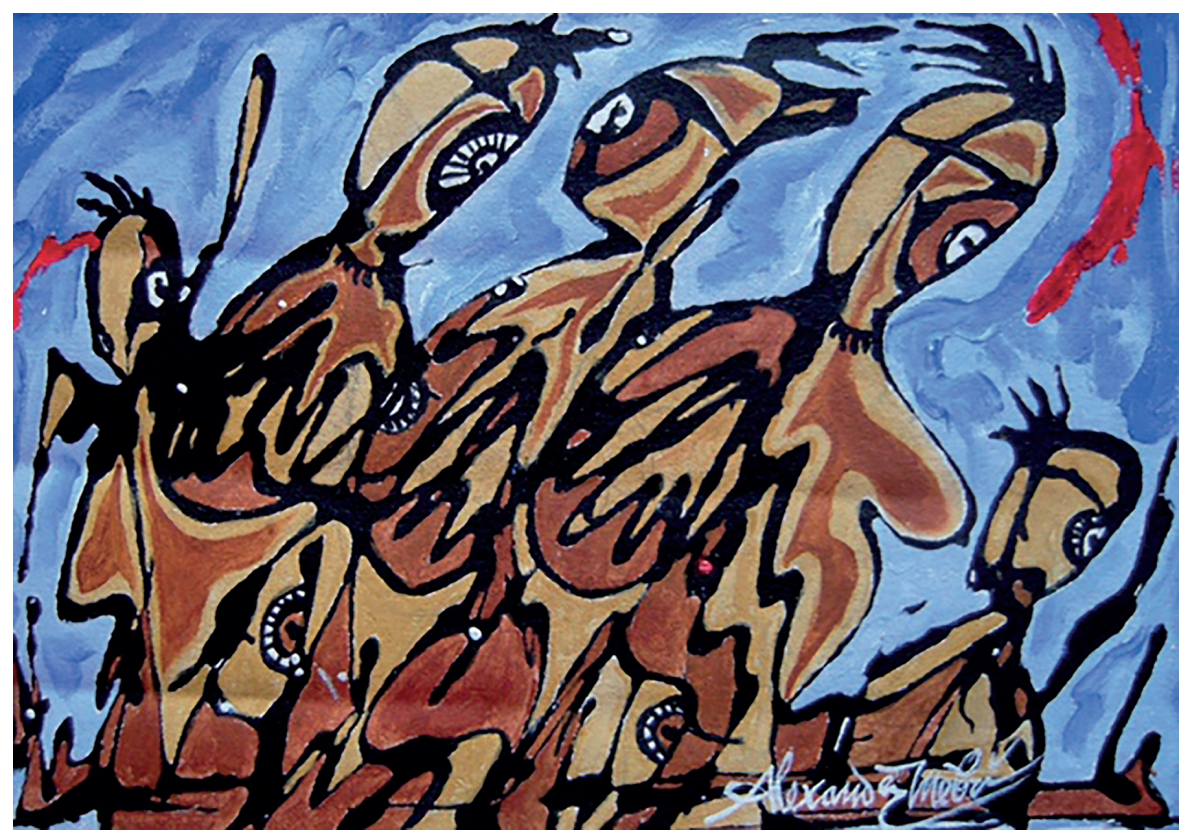

Figure 8.1: Alexander Mebri. "Refugees of the sinking islands, No III,” 2008, Acrylic on Canvas.

The painting by Alexander Mebri ${ }^{88}$ shows a disturbed crowd. Men, women and children are rushing away from their island. They carry their bilum (net bags) with their belongings or an infant inside. They have only a small amount of space

88 Alexander Mebri was born in 1960 in Jayapura, the capital city of what is now Papua Province in Indonesia. His family originated from Yoka Village, Lake Sentani, the home of traditional bark paintings and tapa cloth. In 1998 he crossed the border to Vanimo, Papua New Guinea, as a refugee. Later he moved to Port Moresby to stay with his cousin brother. At the Faculty of Creative Arts, University of Papua New Guinea (UPNG), he enhanced his natural inborn talent in drawing and painting. He graduated in 1994 in Fine Arts. His aim is to emphasize the subject between abstract and reality by driving and losing control of the paint itself producing a special sense of beauty and emotions. He is specialized in painting detailed faces of indigenous people. In a personal communication Alexander stated: "Contemporary art and tribal art both equally remain valid expressions of indigenous cultural values, all my works reflect this culture and are an expression of how it has shaped me from the past to the present." Alexander Mebri has won wide acclaim in PNG and overseas and exhibited in London, Australia and Germany. 
at their disposal. The blue sky merging with the blue ocean evokes a feeling of being lost in a vast environment and escaping into the void. At the same time the painting emphasizes the declining space showing people crowded together. Like all the artists mentioned here Alexander Mebri follows the national discourse on the climate change issue in the media and therefore he also commented on his canvas:

This painting depicts the experiences of the people of the Carteret Islands in Papua New Guinea, whose islands are disappearing through rising sea levels. Their struggle to survive, as their gardens are covered by sea water, has finally resulted in their resettlement on higher land, giving hope to the islanders. ${ }^{89}$

Climate change is provoking these people to migrate further inland and is causing a social security threat due to enhanced population pressure. The tensions intrinsic in migration of people can easily transform into an open conflict as people compete over scarce resources. Access to land for gardening or housing and access to fresh water could gear up further conflicts among the islanders. If villagers start to mark borders, forbidding others to come and fetch water from their community wells the existing order might shift (Böge, 2009).

In her terms Ursula Rakova, executive director and spokeswoman from Tulele Peisa, endorses the picture: "[f] or you it (climate change) is a matter of lifestyle, but for us it is a matter of life and death. If we do not move we are going to be drowned. Our shores are being eaten away. Since more than ten years we are building walls. But the ocean is stronger than us. Nothing can stop the erosion."90

Displacement seems to be unavoidable. Rising sea levels are not only eating away the land of the tiny atolls of the Carteret Islands, but also at their inhabitants' way of life. If the consequences of climate change are admitted, it is like acknowledging that this is inevitable and it feels likes surrender. People want to have a decent life till they come to terms with the irreversible relocation. Migration means homesickness, means losing land rights and means losing voting rights. People don't want to go, they are forced. ${ }^{91}$

\subsection{Displacement and Resettlement}

Fear of the resettlement environment and possible tensions with the host communities leads to strong feelings among the families. They want more safety and security in

89 All statements by Mebri taken from email to author.

90 Personal communication, Hamburg, 14 April 2011.

91 Personal communication, Peter Emberson, Climate Change Campaigns Officer with the Pacific Conference of Churches, Copenhagen, 15 December 2009. 
their new communities. Even though Tulele Peisa had organized meetings between the two groups prior to relocation, uncertainties among the resettlers remain. For instance, the ten Carteret Islanders who had been transferred from the islands to mainland Bougainville in 2009 could not get the legal rights to the land they needed. Potential problems related to landowning and the feeling of insecurity towards the new environment drove them to return to their home island.

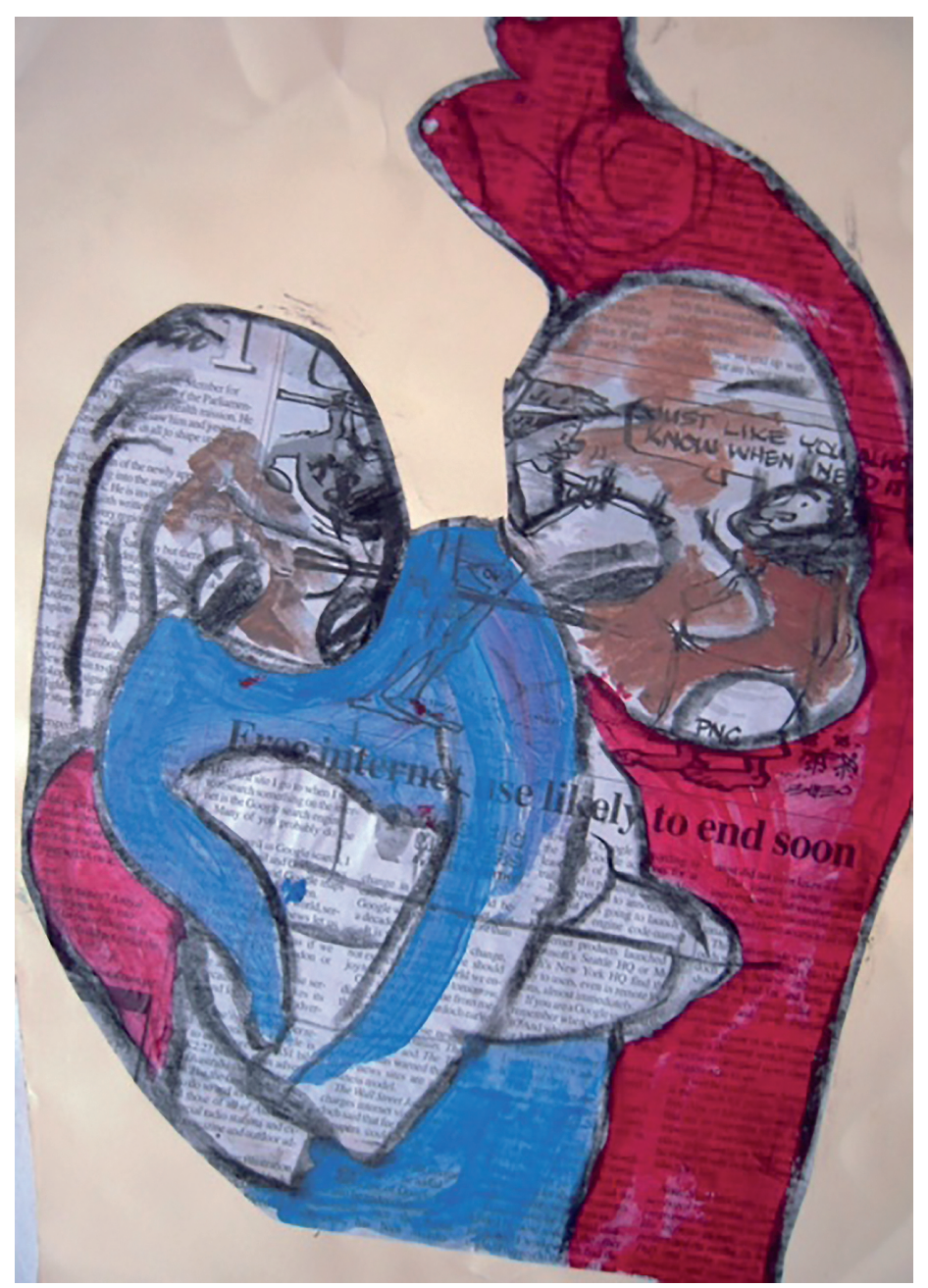

Figure 8. 2: Julie Mota. “Homeless Refugees,” 2009, Mixed media on paper. 
This collage from Julie Mota ${ }^{92}$ pictures a couple. The woman is holding a baby in her arms. They are in distress, moving, fleeing and leaving their hearts behind. People are faced with looming crises or in other words: "we have a feeling of anxiety, a feeling of uncertainty because we know that we will be losing our homes. It is our identity. It is our whole culture at stake," to quote Ursula Rakova again. ${ }^{93}$ This attitude becomes apparent in the remark of a tribal chief of the Carteret Islands, when asked by a journalist: Are you not afraid to stay on the island? He answered: "I am not frightened. If the island is lost, I'm lost too. I'll get lost with the island" ${ }^{94}$

Loss of the land is a disaster. Living on other peoples' land is not an easy way of life. Land is a very high-ranking issue not only in Papua New Guinea but in the Pacific as a whole. Pacific identity is closely connected with land: "the land is part of me and I am part of the land.” Furthermore, land has spiritual quality and connects people with the past, present and future. It is life and nurture and it gives the inhabitants a sense of being and belonging. They burrow the umbilical cord into the ground where the offspring are born and want to be buried at this particular place when they die. The inhabitants are the guardians of the land and want to stay where they belong, maintaining the key link with the land. In short: land holds life together and holds meaning, land equals identity. People's intimate connection to land makes its loss a personal disaster.

If the land is already inundated by salt-water, gardening is becoming a major problem. This adds to the workload of women. They have to find another piece of land to start again to grow a productive food garden. The new garden might be farther away from home and the journey to and from will take a longer time. If there is a shortage of land women's concern increases. They are at the heart of climate change vulnerability (Boncour and Burson, 2010; Struck-Garbe, 2009b).

Even though women have the roles of care giver, agriculture worker and water provider they are mostly marginalised from information about and participation in climate change adaptation and mitigation strategies. As traditional custodians

92 Julie Mota was born 1978 in Lae, Morobe Province. In 1998 she graduated in dramatics and playwriting at the Faculty of Creative Arts at UPNG. She also took drawing classes at UPNG. Her interest in art originates from her family's background. She descends from Tufi in the Oro Province, an area which is famous for its women's face tattoos and tapa clothes. Julie Mota stated in a personal conversation: "For me to follow in my great grandmothers' and grandmothers' footsteps and put ink on paper instead on bark cloth and make my mark in history is a tremendous and privileged task. My work is influenced by traditional legends and stories told by my grandparents." A lot of her work deals with gender issues in contemporary Papua New Guinea and shows women being humiliated or victims of male violence. Another concern of her depicted in her paintings is peril and troubles of modern urban life. Julie Mota's work had been exhibited in Canada, the USA and Germany.

93 Personal communication in Tinputz, Bougainville, Papua New Guinea, March 2011.

94 Marshall, Steve (2007): PNG-Carteret Islands, Broadcast: http: //www.abc.net.au/foreign/content/2007/s1903373.htm 
of the land women have passed on their skills in natural resource management for generations. Through their experiences, they have acquired valuable knowledge that will allow them to contribute positively to the identification of appropriate adaptation and mitigation techniques, if only they are given the chance to voice their ideas or become agents of change. On the Carteret Islands women have accumulated ancestral knowledge about water supplies that will be useful in planning and implementing community level adaptation strategies. Carteret society is matrilineal: mothers now fear that they will never be able to pass their land to their daughters because their heritage will be gone by then.

Despite women being central figures in everyday life and often having considerable knowledge and skills they are mostly excluded when it comes to politics and decisionmaking. This also holds true for resettlement issues. The lack of recognition of the role of women in the use of the land and their right to determine how it is used is a major obstacle in the development of adaptation strategies. This is despite fundamental rights being enshrined in national constitutions and policies, and in international agreements such as the Convention on the Elimination of Discrimination Against Women (CEDAW), which Papua New Guinea has signed and ratified. Women are not only in the face of climate change denied the enjoyments of their rights but the issue is a chance for them to address the key barriers again and demand the observance of their rights.

\subsection{Coral Bleaching and Overfishing}

The small islands of Papua New Guinea are reef-dependent. Pressures on the reef systems represent significant threats to livelihoods and well-being. Strong reefs play a vital role as natural breakwaters minimising wave impacts during storms and cyclones and as a food provider supplying fish (and protein) and sea-food for daily consumption.

Sea temperatures in the tropics have increased by one degree Celsius over the last ten years and are still increasing currently. ${ }^{95}$ Reef building corals become stressed by higher temperatures, they are bleached and die in great numbers. Fewer corals mean less protection and less food for the islanders in times when they are experiencing stronger and heavier storms at the same time (Hoegh-Guldberg, 1999).

Figure 8.3 by Alexander Mebri illustrates people walking on the reef looking for fish and shellfish. They seem to be in panic because they cannot find any seafood. He gives the following statement about his painting: "Marine life in the Pacific is slowly being destroyed, as uncontrolled fishing is being carried out by more developed countries, with bigger ships and sophisticated machinery. The simple coastal villager

95 Marshall, Steve (2007): PNG-Carteret Islands, Broadcast; http: //www.abc.net.au/foreign/content/2007/s1903373.htm 
now struggles to catch fish for his daily family's meal.” His comment points to an additional problem: having fished out their own waters, countries like Japan, Taiwan, Korea, China, the United States and Spain are now sending their industrial fishing fleets to the Pacific to exploit the region's stocks. Overfishing is seriously depleting tuna stocks and destructive fishing practices are killing other valuable marine life. Pacific Island countries are being exploited for their resources. For them the ocean is no longer the provider of food. This is a terrifying situation and such a threat to the sustainability of the entire social-eco-system of the islands that it obviously forces the islanders to act desperately.

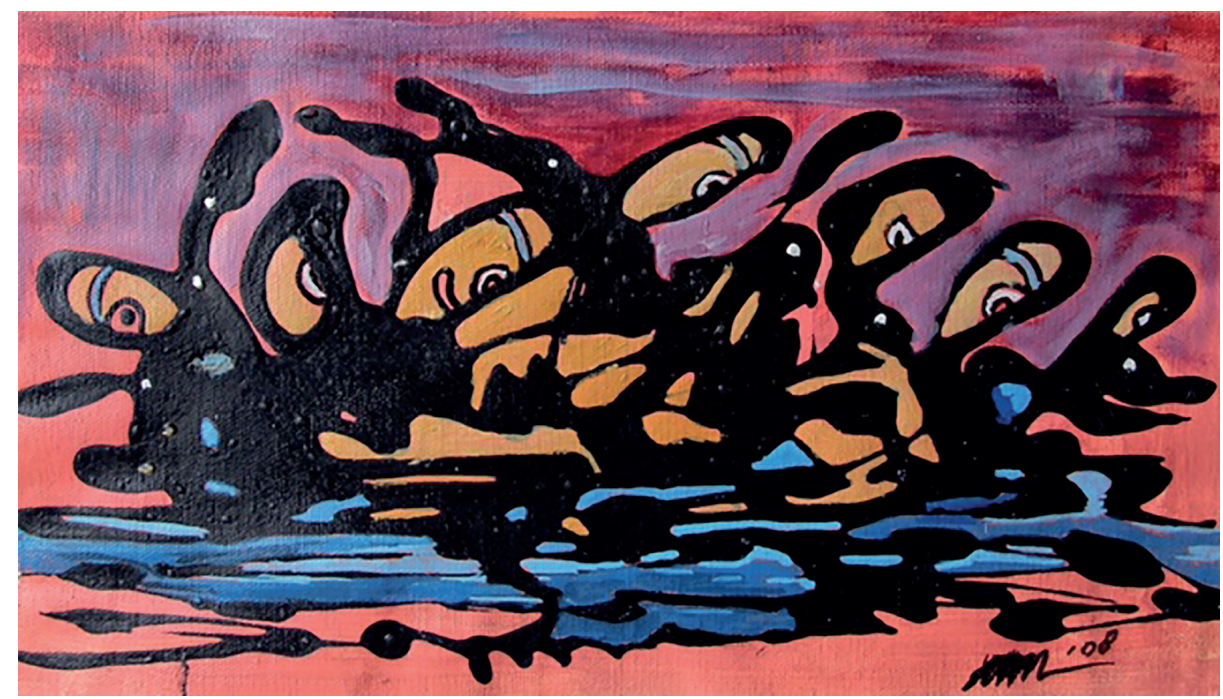

Figure 8.3: Alexander Mebri. "Where has my fish gone, No II," 2008, Acrylic on Canvas.

\subsection{Deforestation}

The importance of the forest and the necessity for reducing emissions from deforestation was quickly recognized by Papua New Guinea's then long-time Prime Minister Michael Somare. He said at the UNFCCC COP 13/CMP3 meeting in Bali in December 2007: "If we lose the world's forests we lose the fight against climate change. Rainforests are our earth's greatest utility-our planet's lungs, thermostat, and air-conditioning system." 96 Despite this comprehension the Somare government

96 Spiegel Online Wissenschaft: 02.05.2011, Prognose: Meeresspiegel steigt stärker als erwartet; http: //www.spiegel.de/wissenschaft/natur/0,1518,760148,00.html 
continued to facilitate the expansion of large-scale industrial and destructive logging. Over the past years successive governments before and after him have favoured industry over the environment, staunchly defending the interests of foreign logging companies and supporting their illegal activities. Local people have not benefited from large-scale foreign owned development and industries, and government corruption does not effectively manage revenue from extractive and lumber developments so that services like hospitals, roads and schools are available to the population. Furthermore, the public also does not have the information available to hold the government accountable for mismanagement.

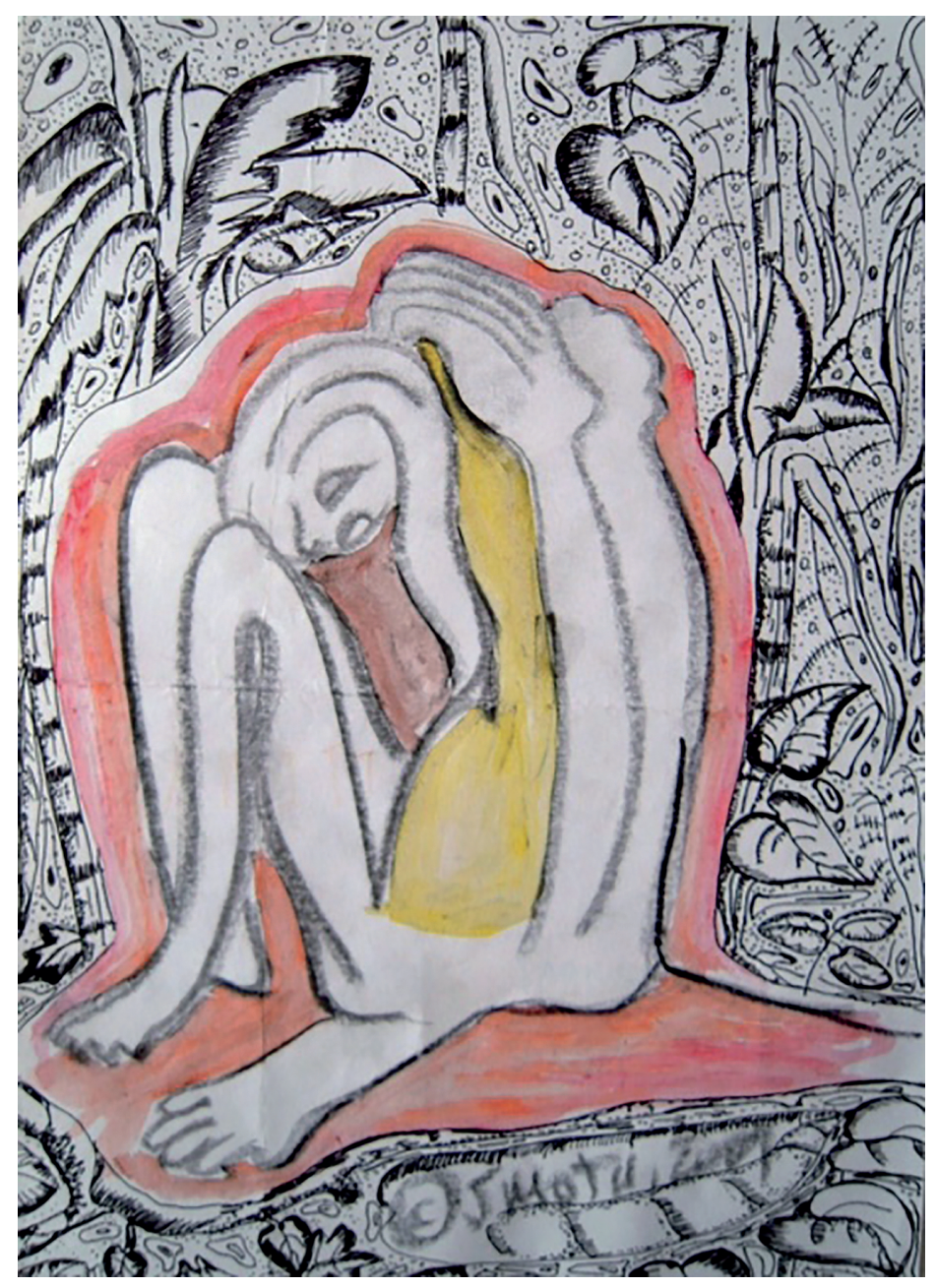

Figure 8.4: Julie Mota. “Forest Concern,” 2009, Pen illustration, charcoal and watercolor on paper. 
Although much of this area is still untouched Papua New Guinea is losing the struggle against forest degradation due to current policies and practices. Poor governance and a high level of corruption have led to large-scale illegal logging. Forest management is poor. The people have seen no benefit from logging, just destruction. At some stage, they thought they give away forest for development. According to a former missionary and landowner Brother Jim Coucher from Vanimo: "At first they welcome the loggers because they think it might mean money, but in fact they get very little out of it. The loggers don't do any replanting or clearing up at all ... and they give no benefits to the people. They use bulldozers to drag the logs which create all sorts of problems with erosion." 97 Forest protection on the one hand and small-scale eco-forestry on the other could be a way to slow down the speed of destruction and to solve the problems of forest loss.

In "Bush Fire" Alexander Mebri depicts a couple who is involved in inflaming a bush fire. In the background, there are other people standing closer to the origin of the fire. In the flames appear the eyes of their ancestors watching and crying with black tears. The eyes are also symbolising the soul of the forest. The artist comments on his works as followed: "Bush fires, one cause of climate change in the world today, are caused by uncontrolled burning of forests to make more gardens as population increases."

A significant threat to Papua New Guinea's forests is agricultural expansion. The country's high population growth rate (3.1\%) means increasing amounts of land are converted for subsistence agriculture. Each year 50,000-60,000 h.a. are cleared totally and permanently: 45\% for agriculture, $48 \%$ for industrial logging, and the rest for infrastructure ${ }^{98}$. As the population neared 7.8 million in 2014 with over $80 \%$ of this population living a traditional rural subsistence lifestyle, the capacity of the ecosystems to continue to support the country's rural population has come under threat. More people impose greater demands on natural resources. Over the past 30 years, the country's population has more than tripled, from 2.1 million to 7.3 million in $2011 .{ }^{99}$

Typically, fire is used for land-clearing and at times-especially during dry El Niño years-agricultural fires can go out of control. During the 1997-8 El Niño events, fires burned thousands of hectares of dried-out forest while hundreds of people died from food shortages and famine in the central highlands.

97 http: //www.planetark.com/dailynewsstory.cfm/newsid/45991/newsDate/13-Dec-2007/story.htm 98 Zwartz, Barney (27.02.2010): Rampant logging, destroying PNG; http: //www.smh.com.au/environment/rampant-logging-destroying-png-20100226-p94l.html

99 http://www.islandsbusiness.com/news/papua-new-guinea/4378/pngs-population-stands-ataround-78-milliongrowth-/ (24 January 2014). 


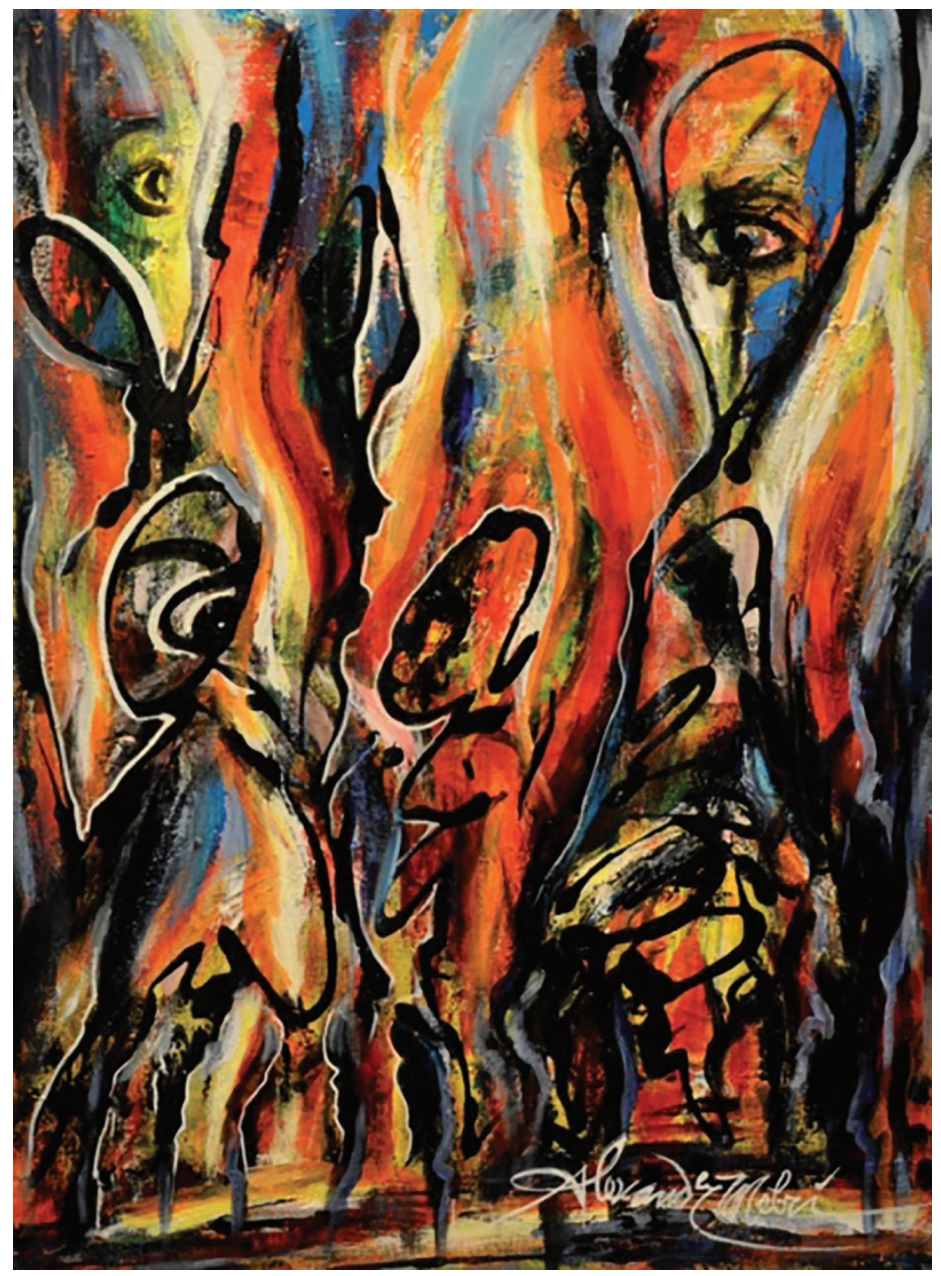

Figure 8.5: Alexander Mebri. “Bush Fire,” 2008, Acrylic on Canvas.

One aspect of Alexander Mebri's statement is based on the assumption that the smaller forests are, the less carbon dioxide $\left(\mathrm{CO}_{2}\right)$ is absorbed by trees; this then accumulates in the atmosphere as a result of pollution. Deforestation is one of the main causes of climate change, accounting for almost a fifth of all greenhouse gas emissions. At the same time, there will be an increased presence of $\mathrm{CO}_{2}$ if trees are being burnt or being logged (Greenpeace, 2008).

The greatest hazard for the ecology of the rainforest in Papua New Guinea derives from industrial logging. Officially it is the so-called "selected logging" that takes place. However, in fact at the present, as well as for the past two decades, forest harvesting has occurred in a destructive and in an ecologically unsustainable fashion. Phil Shearman's report shows nearly one quarter of the rainforest was damaged or 
destroyed between 1972 and 2002 (Shearman et al, 2009). The numbers indicate that Papua New Guinea cannot and does not regulate forest operations. Under the Special Agricultural Business Leases (SABLs)-introduced in 1996 and meant to develop small-scale agricultural projects on the local level-a rapid deforestation happened which was accompanied with a huge land grab. Over 5 million hectares $(12 \%$ of Papua New Guinea's landmass) of customarily owned land has been given to foreign companies for 99 year leases despite landowners' opposition. This deed violated the rights of indigenous people and caused harm to their livelihoods and the natural resources they depend on. The government yet is still failing to take a meaningful action to address this problem. Meanwhile the deforestation goes on.

\subsection{Pacific Islands and the Global Challenge}

The impacts of climate change are being felt hardest by some of the world's poorest and remote communities with little opportunity or support for adaptation to these impacts. In 2008, Kiribati's then President Anote Tong said at an environmental conference in New Zealand: "The climate change is not an issue of economic development; it is an issue of human survival." ${ }^{100}$ But nothing has changed. The emissions in the atmosphere will carry on contributing to climate change, so the small low-lying islands will be submerged within this century, according to the worst-case scenarios.

Ursula Rakova is riled at this perspective. "We are angry. Some of our people do not understand the science, but they know they are losing their homes and they are angry they have to pay for what other people in industrialised nations have done."101 John Danger ${ }^{102}$ illustrates her comment.

100 United Nations Environment Programme: The Environment in the News, 2008, 6 June, World Environment Day Coverage, p. 12

101 Morton, Adam (28 July 2009): First climate refugees start move to new island home; http: //www. theage.com.au/national/first-climate-refugees-start-move-to-new-island-home-20090728-e06x.html 102 John Danger Ulka was born in 1969 in the village of Kakagl in the Simbu Province where he grew up and went to a local school. In 1999 he moved to Port Moresby and became a grass roots artist without any formal training. His paintings depict scenes of the people and their surroundings of his home country in a kind of naive and two-dimensional way. John's paintings are popular with the tourists and local people including business houses in Port Moresby. He is currently the spokesperson for all so-called street artists in Port Moresby. John Danger is well-known in Papua New Guinea and has been participating in art shows and exhibitions in the country for many years. 


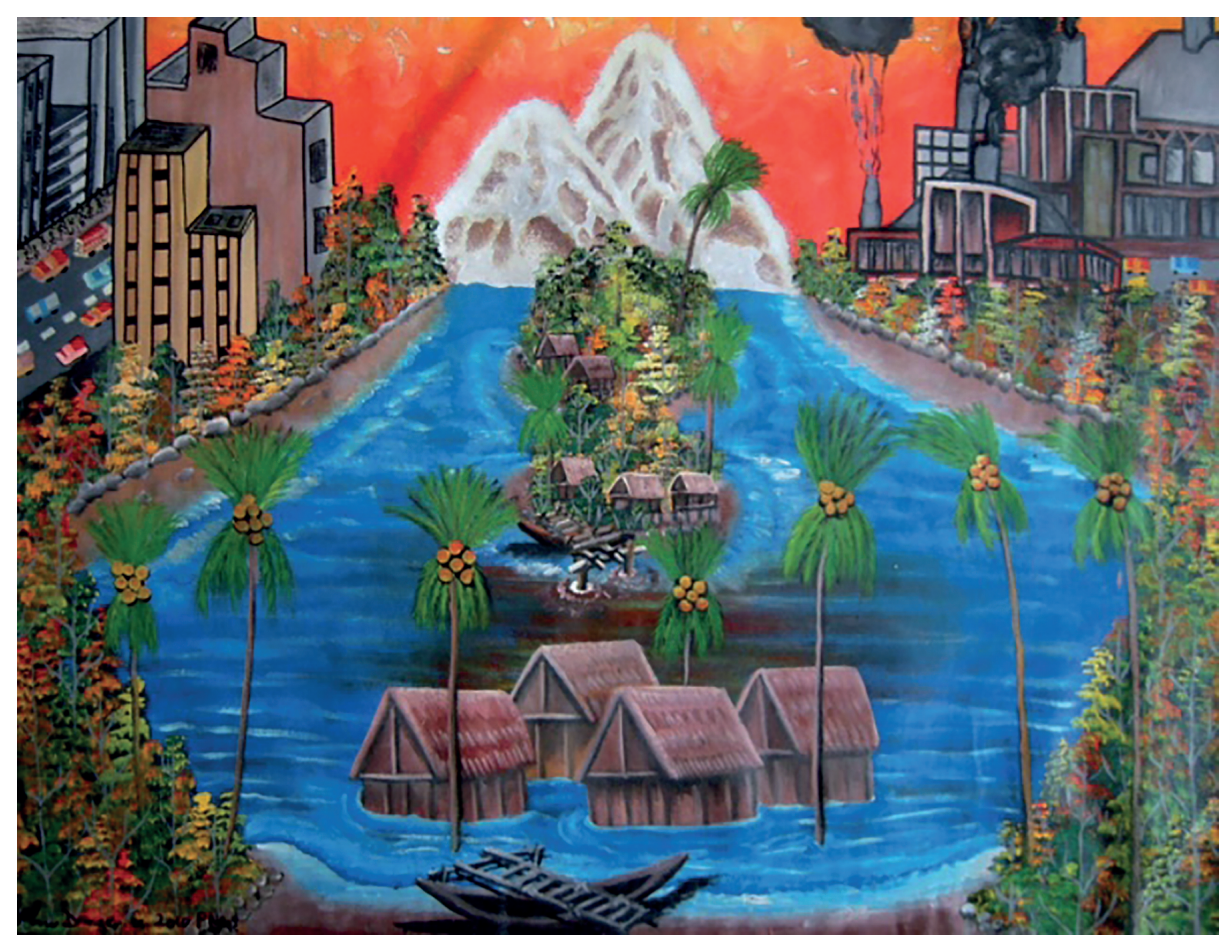

Figure 8.6: John Danger. “Climate Change,” 2009, Acrylic on Material.

In his painting, he depicts the human influence on climate change. Industrial activities in the developed countries produce carbon dioxide and increase the greenhouse gases' concentration while the island village is drowned due to sea level rise. Despite the fact that Pacific Island countries are low-emitters of greenhouse gases, they are in fact among the most vulnerable to the adverse impacts of climate change. They are the first victims of climate change, which tremendously hampers their development.

The concerted call of Pacific Island nations for a globally coordinated response to climate change for years seems to trail off unheard. The people fear that many of the islands will disappear under the ocean if climate change is allowed to continue.

The consequences of climate change are already felt in Papua New Guinea and discussed in the mass media by NGOs, politicians and church representatives. Contemporary art in some parts has always dealt with the problems of modernity in the country and has now taken up climate change as a theme. Living in a contemporary society that is culturally diverse, rapidly changing and threatened by environmental disasters and damages means it is important that the arts of this society embrace and reflect these changes. Art is a sensor of society and it challenges perceptions of climate change by visualising the feelings of threat and danger that 
come along with climate change. Even though artists want to be relevant in their culture and society they see their artwork also as a message to the outside, to the global world. The underlying narrative acknowledges that the rich countries have responsibility for the current excess of carbon in the atmosphere, and therefore should support the poor countries in their fight against the consequences of climate change. Their paintings can be seen as participating in an unfolding and contested conversation between North and South. 